\title{
The Health Evaluation of RCC Silo Using Non-Destructive Methods
}

\author{
${ }^{1}$ Akshay Ambade, ${ }^{2}$ Nikhil Pitale, ${ }^{3}$ Dr.Diip Mase \\ ${ }^{1}$ Civil Engineering Department, G.H.Raisoni College of Enginnering, Nagpur, Maharashtra, India \\ ${ }^{2}$ Assistant Professor, Civil Engineering Department, G.H.Raisoni College of Enginnering, Nagpur, Maharashtra, \\ India \\ ${ }^{3}$ Director of P T MASE \& ASSOCIATES, Nagpur, Maharashtra India
}

\begin{abstract}
A silo may be a structure for storing bulk materials. Silo is utilized in agriculture to store grain or fermented feed referred to as silage. Silo is commonly used for bulk storage of grain, coal, cement, smut, woodchips, food products and sawdust. Three kinds of silos are in widespread use today: tower silos, bunker silos, and bag silos. Every structure needs health evaluation after some time it known as condition assessment of structure. When structure complete, 10 year \& found any default in structure then we need to do Non-destructive testing like Ultra-sonic pulse velocity test, Rebound hammer test and Half-cell potential meter test.
\end{abstract}

Keywords : - Ultra Sonic Velocity Test, Rebound Hammer Test, Half-Cell Potential Meter Test.

\section{INTRODUCTION}

Silos are employed by a good range of industries to store bulk solids in quantities starting from some tones to hundreds or thousands of tones. The term silo includes all sorts of particulate solids storage structure that may preferably be stated as a bin, hopper, grain tank or bunker. They will be constructed of steel or reinforced concrete and should discharge by gravity flow or by mechanical means. They can be supported on columns, load bearing skirts, or they may be hung from floors.

Some causes of failure of RCC Silo's.

- Failure due to structural design.

- Failure due to maintenance.

- Failure due to construction error.

Storage silos are cylindrical structures, typically 3 to 27 meter in diameter and 10 to 90 meters in height with slip and jump from concrete silos being the larger diameter and taller silos. Bunker silo are trenches, usually with concrete walls, that are filled and packed with tractor.

\section{LITERATURE REVIEW}

[1]Nikhil L. Jagtap, Prof. P.R. Mehetre, in this project, condition of the present structure is assessed using NDT'S and it's proposed to increase the structure. The building was designed in step with the state of the art over 40 years ago it didn't meet this day requirement. The project study deals with strengthening and enhancement of performance of existing structure so structure can perform well when subjected to additional loads over it. This work deals with NDT on existing structural elements/determination of load and moment carrying capacity of structural elements before and after extension, method applied for strengthening of structure, design of the present structural elements like R.C.C beams and columns in step with the load carrying capacity required. This work is further extended to: Strengthening of the 
present structure with different retrofitting techniques, Study on the performance of the present structure after retrofitting.

[2]Namitha R. Jain, Mr. K. N. Vishwanath, in these Non-Destructive Evaluation (NDT) techniques, are getting used for Structural Health Evaluation. Structures are assemblies of load carrying members capable of safely transferring the superimposed loads to the foundations. Their main and most sorted property is that the strength of the fabric that they're product of. Concrete, as we all know, is an integral material used for construction purposes. Thus, strength of concrete used, is required to be 'known' before starting with any quite analysis. The varied methods and techniques, called as NDT. In recent years, innovative NDT methods, which may be used for the assessment of existing structures, became available for concrete structures, but are still not established for normal inspections. Therefore, the target of this project is to review the applicability, performance, availability, complexity and restrictions of NDT. On concluding the recommended strengthening measures effectively by an experienced agency under the supervision of experienced personnel, the deficient R.C footings and columns of basement and ground floor are going to be rendered normal and bear the expected loads.

[3]Pascale et al. (2003) Carried out an experimental program involving both destructive and nondestructive methods applied different concrete mixture, with cube strength varying from 30 to 150 $\mathrm{MPa}$, to define a relation between strength and parameter are pulse velocity, rebound hammer, pull out and probe penetration and combine method.

[4]Almir and Protasio (2000), used NDT method see the compressive strength of concrete relationship between the measured mechanical and also the strength also presented the validity of pull off, pin penetration and UPV for assessing the concrete strength.

[5]Rens and Kim (2007), inspected a steel bridge using several NDT method like visual inspection, hammer sounding, Schmidt hammer, and UPV testing, results of NDT had been used to determine area, to be tested with local destructive test like compressive strength, chloride testing and magnetic cover meter are widely used to estimate the cover to steel bars.

\section{METHODOLOGY}

1. To carry out visual inspection of silo and collect the details of structure with the help of structural drawings.

2. Carry out following test on structure.

a) Ultrasonic Pulse velocity Test (UPV Test).

b) Rebound Hammer Test.

c) Half-cell Potential Meter Test

3. To prepare surface for test.

\section{A. Ultrasonic pulse velocity test}

This test is done to assess the quality of concrete by ultrasonic pulse velocity method as per IS: 13311(part1)-1992.The underlying principle of the test is -The method consists of measuring the time of travel an ultrasonic pulse passing through the concrete being tested. Comparatively higher velocity is obtained when concrete quality is good in term of density, uniformity, homogeneity etc.

\section{Interpretation of Results}

The quality of concrete in terms of uniformity, incidence or absence of internal flaws, crack and segregation, etc. indicative of the extent of workmanship employed, can thus be assessed using the rules given below, which are evolved for characterizing the standard of concrete in structures in terms of the ultrasonic pulse velocity. 
Table No.1: -UPV Test Result Calculation.

\begin{tabular}{|c|c|}
\hline Pulse velocity $(\mathrm{km} / \mathrm{sec})$ & Concrete Quality \\
\hline Above 4.5 & Excellent \\
\hline 3.5 to 4.5 & Good \\
\hline 3.0 to 3.5 & Medium \\
\hline Below 3.0 & Doubtful \\
\hline
\end{tabular}

\section{B. Rebound Hammer Test}

A Schmidt hammer could be a device to live the strength of concrete mainly surface hardness and penetration resistance. The hammer measures the rebound of a spring-loaded mass impacting against the surface of a sample. The test hammer hits the concrete at an outlined energy. Its rebound relies on the hardness of the concrete and is measured by the equipment. By conversion chart, the rebound value may be wont to determine the concrete's compressive strength.

\section{Interpretation of Result}

The rebound hammer reading on the indicator scale has been calibrated by the manufacturer of the rebound hammer for horizontal impact, that's on a surface, to point the compressive strength. When employed in the other position, appropriate correction as given by the manufacturer is taken under consideration.

Table No.2: - Rebound hammer result calculation

\begin{tabular}{|c|c|}
\hline $\begin{array}{c}\text { Average Rebound } \\
\text { Number }\end{array}$ & Quality of Concrete \\
\hline$>40$ & Very good \\
\hline 30 to 40 & Good layer \\
\hline 20 to 30 & Fair \\
\hline$<20$ & Poor Concrete \\
\hline
\end{tabular}

\section{Half-cell Potential Meter Test}

Half-Cell Potential Test is a very important method for assessing the severity of corrosion activity in concrete structures the tactic of half-cell potential measurements normally involves measuring the potential of an embed reinforcing bar relative to a reference half-cell normally a copper/ cupric sulphate placed on the concrete surface.

Table No.3: - Risk of Corrosion against Potential Difference Reading.

\begin{tabular}{|c|c|c|}
\hline Sr. No. & $\begin{array}{c}\text { Half-cell }(\mathrm{mv}\} \\
\text { relative to } \mathrm{Cu}-\mathrm{Cu} \\
\text { sulphate }\end{array}$ & $\begin{array}{c}\text { \% chance of } \\
\text { corrosion activity }\end{array}$ \\
\hline 1 & Less than -200 & $10 \%$ \\
\hline 2 & $\begin{array}{c}\text { Between }-200 \text { to }- \\
350\end{array}$ & $50 \%$ (uncertain) \\
\hline 3 & Above-350 & $90 \%$ \\
\hline
\end{tabular}

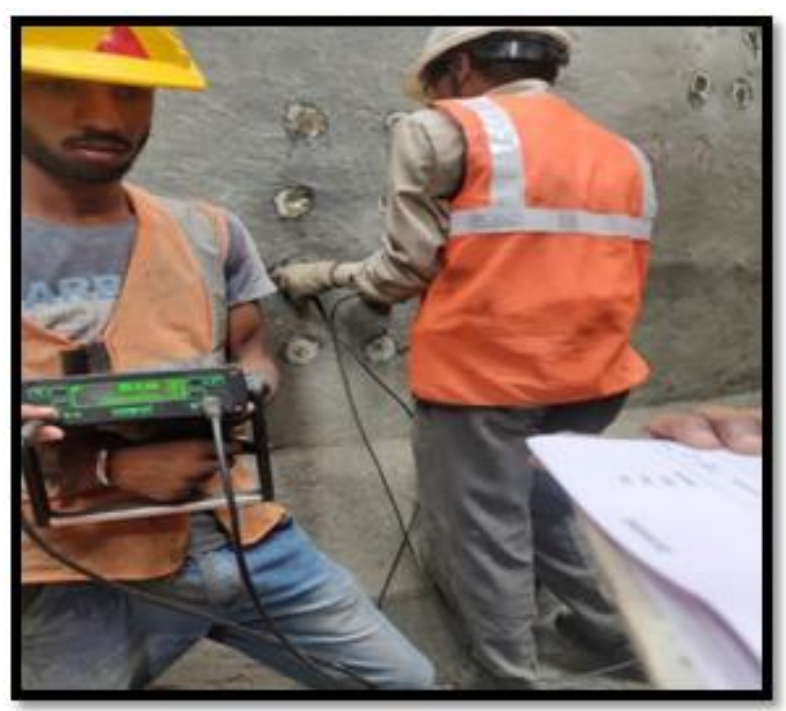

Fig No.1: - UPV Test 


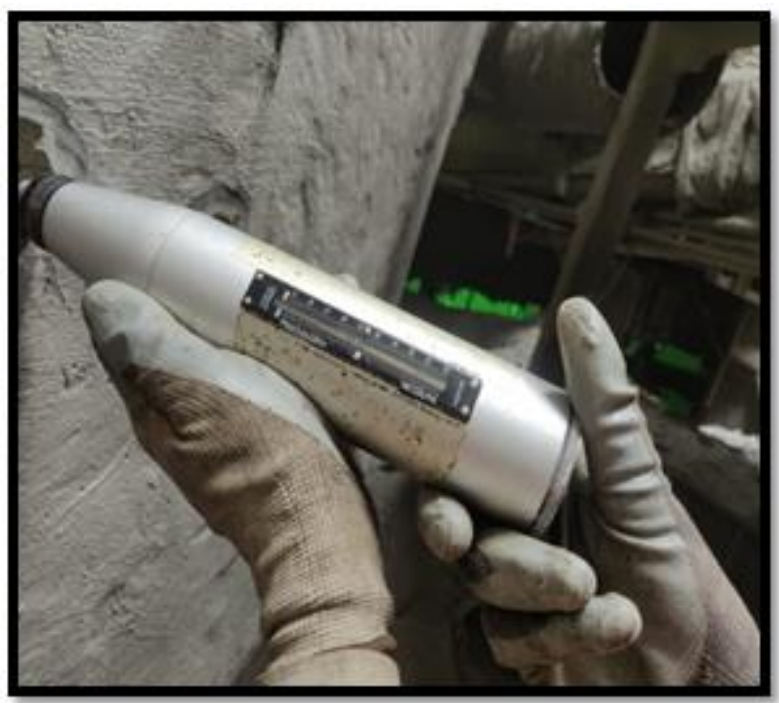

Fig 2: - Rebound Hammer Test

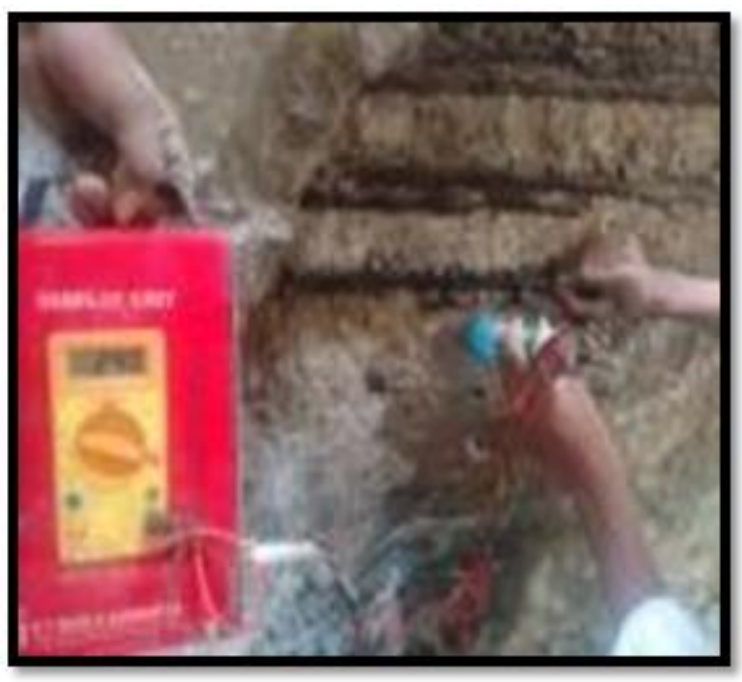

Fig 3: - Half Cell Potential Test

IV. RESULTS

A. Ultrasonic pulse velocity test

Table No.4 : - UPV Test Results

\begin{tabular}{|c|c|c|c|c|c|c|c|}
\hline Sr. & Description & Particular & $\begin{array}{l}\text { Transit } \\
\text { time } \\
\text { in } \\
\text { Micro } \\
\text { Seconds } \\
\text { (T) }\end{array}$ & $\begin{array}{c}\text { Path } \\
\text { length } \\
(\mathrm{L}) \\
(\mathrm{mm})\end{array}$ & $\begin{array}{l}\text { Velocity } \\
\mathrm{V}=(\mathrm{L} / \mathrm{T}) \\
(\mathrm{Km} / \mathrm{Sec})\end{array}$ & $\begin{array}{c}\text { Factored } \\
\text { value }\end{array}$ & Remark \\
\hline \multicolumn{8}{|c|}{ CEMENT SILO } \\
\hline \multirow{3}{*}{1} & \multirow{3}{*}{$\begin{array}{c}\text { West Side At } 2.0 \mathrm{Mtr} \\
\text { Level }\end{array}$} & Indirect & 100 & 200 & 2 & 3 & Medium \\
\hline & & Indirect & 99.5 & 200 & 2.01 & 3.01 & Medium \\
\hline & & Indirect & 101.5 & 200 & 1.97 & 2.97 & Doubtful \\
\hline \multirow{3}{*}{2} & \multirow{3}{*}{$\begin{array}{c}\text { West Side At } 4.0 \mathrm{Mtr} \\
\text { Level }\end{array}$} & Indirect & 123.5 & 200 & 1.62 & 2.62 & Doubtful \\
\hline & & Indirect & 102.3 & 200 & 1.96 & 2.96 & Doubtful \\
\hline & & Indirect & 102.3 & 200 & 1.96 & 2.96 & Doubtful \\
\hline \multirow{3}{*}{3} & \multirow{3}{*}{$\begin{array}{c}\text { West Side At 6.0 Mtr } \\
\text { Level }\end{array}$} & Indirect & 98.6 & 200 & 2.03 & 3.03 & Medium \\
\hline & & Indirect & 101.1 & 200 & 1.96 & 2.96 & Doubtful \\
\hline & & Indirect & 98.6 & 200 & 2.03 & 3.03 & Medium \\
\hline \multirow{2}{*}{4} & \multirow{2}{*}{$\begin{array}{c}\text { West Side At 8.0 Mtr } \\
\text { Level }\end{array}$} & Indirect & 106.6 & 200 & 1.88 & 2.88 & Doubtful \\
\hline & & Indirect & 108.3 & 200 & 1.85 & 2.85 & Doubtful \\
\hline
\end{tabular}




\begin{tabular}{|c|c|c|c|c|c|c|c|}
\hline & & Indirect & 101.2 & 200 & 1.98 & 2.98 & Doubtful \\
\hline \multirow{3}{*}{5} & \multirow{3}{*}{$\begin{array}{c}\text { West Side At } 10.0 \mathrm{Mtr} \\
\text { Level }\end{array}$} & Indirect & 92.7 & 200 & 2.16 & 3.16 & Medium \\
\hline & & Indirect & 97.9 & 200 & 2.04 & 3.04 & Medium \\
\hline & & Indirect & 101.1 & 200 & 1.96 & 2.96 & Doubtful \\
\hline \multirow{3}{*}{6} & \multirow{3}{*}{$\begin{array}{c}\text { West Side At } 12.0 \mathrm{Mtr} \\
\text { Level }\end{array}$} & Indirect & 117.3 & 200 & 1.71 & 2.71 & Doubtful \\
\hline & & Indirect & 108.3 & 200 & 1.85 & 2.85 & Doubtful \\
\hline & & Indirect & 99.5 & 200 & 2.01 & 3.01 & Medium \\
\hline \multirow{3}{*}{7} & \multirow{3}{*}{$\begin{array}{c}\text { West Side At } 14.0 \mathrm{Mtr} \\
\text { Level }\end{array}$} & Indirect & 123.5 & 200 & 1.62 & 2.62 & Doubtful \\
\hline & & Indirect & 101.5 & 200 & 1.97 & 2.97 & Doubtful \\
\hline & & Indirect & 102.3 & 200 & 1.96 & 2.96 & Doubtful \\
\hline
\end{tabular}

\section{B. Rebound Hammer Test}

Table No.5 : - Rebound Hammer Results

\begin{tabular}{|c|c|c|c|c|}
\hline $\begin{array}{c}\text { Sr. } \\
\text { No. }\end{array}$ & Particulars & Rebound No. & Average & $\begin{array}{c}\text { Probable } \\
\text { Compressive } \\
\text { Strength } \\
\text { (N/mm2) }\end{array}$ \\
\hline CEMENT SILO & & \\
\hline 1 & West South Side At 7.0 Mtr Level & $40,42,42,38,48,42,42,36,38$ & 41 & 46 \\
\hline 2 & West South Side At 9.0 Mtr Level & $38,40,42,42,34,36,48,32,46$ & 40 & 44 \\
\hline 3 & West South Side At 11.0 Mtr Level & $42,38,36,38,28,44,42,28,32$ & 36 & 37 \\
\hline 4 & West South Side At 13.0 Mtr Level & $28,32,22,26,42,26,24,32,34$ & 30 & 27 \\
\hline 5 & West South Side At 15.0 Mtr Level & $28,32,44,42,48,24,26,28,30$ & 34 & 34 \\
\hline 6 & West South Side At 17.0Mtr Level & $34,40,44,46,42,38,36,48,42$ & 41 & 46 \\
\hline 7 & West South Side At 22.0 Mtr Level & $40,38,40,36,34,42,42,38,42$ & 39 & 43 \\
\hline 8 & West South Side At 24.0 Mtr Level & $44,40,42,40,42,42,38,40,42$ & 41 & 46 \\
\hline
\end{tabular}

\section{Half-cell Potential Meter Test}

Table No.6: - Risk of Corrosion against Potential Difference Reading

\begin{tabular}{|c|c|c|}
\hline \multirow{2}{*}{ Sr. No. } & Particulars & Half Cell \\
\hline \multirow{2}{*}{1.} & \multirow{2}{*}{ West Side At 2 Mtr Level } & -239 \\
\cline { 3 - 3 } & & -242 \\
\cline { 3 - 3 } & & -244 \\
\hline \multirow{2}{*}{2.} & \multirow{2}{*}{ West Side At 4 Mtr Level } & -236 \\
\cline { 3 - 3 } & & -227 \\
\hline \multirow{2}{*}{3.} & \multirow{2}{*}{ West Side At 6 Mtr Level } & -226 \\
\cline { 3 - 3 } & & -221 \\
\hline
\end{tabular}




\begin{tabular}{|l|l|l|}
\hline & & -220 \\
\hline \multirow{3}{*}{4.} & \multirow{3}{*}{ West Side At 8 Mtr Level } & -234 \\
\cline { 3 - 3 } & & -222 \\
\cline { 3 - 3 } & & -199 \\
\cline { 3 - 3 } & & -311 \\
\hline
\end{tabular}

\section{CONCLUSION}

Ultrasonic pulse velocity test (refer IS 13311 part-1 1992) result applying indirect method, maximum reading found between $2.62 \mathrm{Km} / \mathrm{sec}$ to $3.16 \mathrm{~km} / \mathrm{sec}$. Reading shows the quality of concrete is doubtful at maximum location and medium at few locations. RCC silo need Repair and Strengtning work with help of grouting techniques.

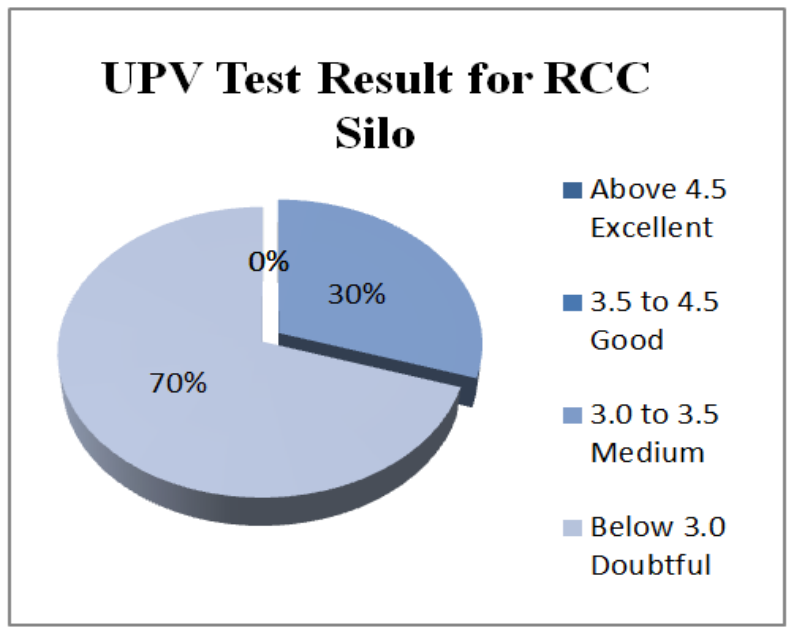

Fig. 4 UPV Test Result Chart

A. Rebound Hammer Test the previous data silo is design by M50 Grade concrete and after Rebound hammer test (refer IS 13311 part-1 1992) all reading gives result between M27 to M46 Grade of concrete. Grade of concrete is improved when grouting techniques is used.

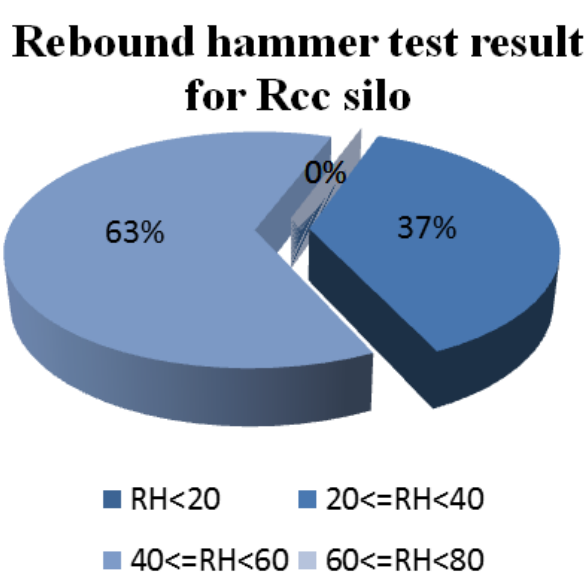

Fig.5 Rebound Hammer Test Result Cart

B. Half-cell potential test $50 \%$ corrosion occurs in silo. For the betterment of silo need to do remedial measure use anti-oxidant removed the rusting and use retrofitting to silo.

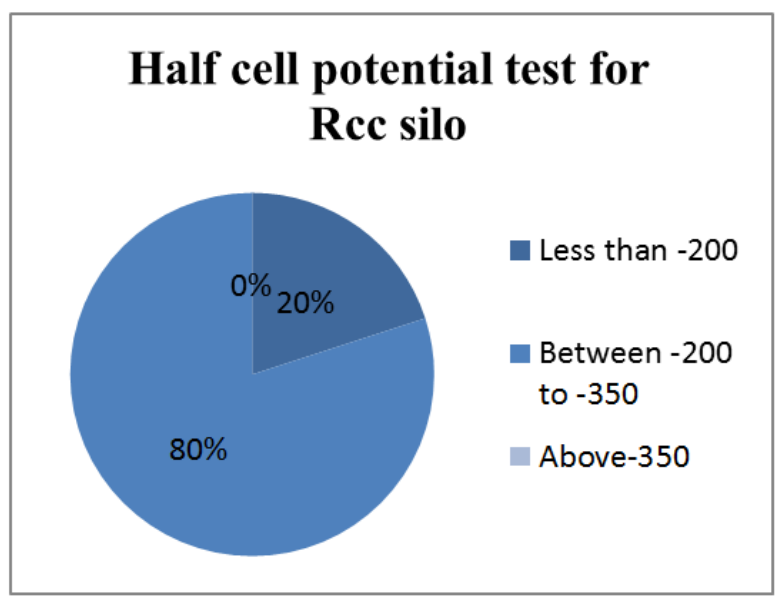

Fig.6 Half Cell Test Result Chart 


\section{REFERENCES}

[1]. Nikhil L. Jagtap1, Prof. P.R. Mehetre. "Study on Retrofitted R.C.C. Building by Different NDT Methods"(IOSR-JMCE): IOSR Journal of Mechanical and Civil Engineering. Issue 3 ver. I May. - Jun. 2015.

[2]. Namitha R. Jain, Mr. K N. Vishwanath "Strength Assessment and Restoration of Rcc Structures by structural Health Evaluation" in (IJERT) International Journal Engineering Research \& Technology. Vol. 2 Issues 7, July

[3]. G. Pascale, A. D. Leo, and V. Bonora, "Nondestructive assessment of the actual compressive strength of high-strength concrete," Journal of Materials in Civil Engineering, vol. 15, no. 5, pp. 452-459, 2003.

[4]. P. F. Almir and F. C. Protasio, "Application of NDT to concrete strength estimation," NDT.Net, vol. 5 , no. 2 ,

[5]. K. L. Rens and T. Kim, "Inspection of Quebec street bridge in Denver, destructive and nondestructive testing," Journal of Performance of Constructed Facilities, vol. 21, no. 3, pp. 215224, 2007.

[6]. IS 13311:1992 (Part 1); Indian Standard code of practice for Non Destructive Testing of Concrete- Method of test (Ultrasonic Pulse Velocity).

[7]. IS 13311:1992 (Part 2); Indian Standard code of practice for Non Destructive Testing ConcreteMethod of test (Rebound Hammer).

[8]. IS 516:1959; Indian Standard code of practice for Method of tests for Strength of Concrete.

\section{Cite this article as :}

Akshay Ambade, Nikhil Pitale, Dr. Diip Mase, "The Health Evaluation of RCC Silo Using Non-Destructive Methods", International Journal of Scientific Research in Science and Technology (IJSRST), Online ISSN : 2395-602X, Print ISSN : 2395-6011, Volume 7 Issue 3, pp. 190-196, May-June 2020. Available at doi : https://doi.org/10.32628/IJSRST207331 Journal URL : http://ijsrst.com/IJSRST207331 